\title{
GROWTH HORMONE, GROWTH HORMONE RECEPTOR AND INSULIN-LIKE GROWTH FACTOR SERUM LEVELS IN PATIENTS WITH OBESITY AND FOOD ADDICTION
}

\author{
O. AVSAR ${ }^{1 凶, ~ S . ~ S A N C A K ~}{ }^{2}, I . K O R O G L U^{3}, E . A V C I^{4}$ \\ ${ }^{1}$ Hitit University, Department of Molecular Biology and Genetics, Corum, Turkey; \\ ${ }^{2}$ Fatih Sultan Mehmet Education and Research Hospital, Department of Endocrinology, Istanbul, Turkey; \\ ${ }^{3}$ Arapgir Ali Özge State Hospital, Department of Internal Medicine, Malatya, Turkey; \\ ${ }^{4}$ Health Sciences University, Department of Biochemistry, Ankara, Turkey; \\ e-mail: orcunavsar@hitit.edu.tr
}

Received: 27 May 2021; Accepted: 12 November 2021

Obesity is a public health problem that increasingly becomes widespread and causes various complications. Food addiction is a hedonic eating behavior characterized by overconsumption of palatable foods (i.e., foods involve a high amount of salt, sugar and fat). Disturbances in the growth hormone signaling pathway were shown to be associated with increased food intake and adiposity. The study aimed to determine the growth hormone (GH), growth hormone receptor (GHR), insulin, and insulin-like growth factor 1 (IGF-1) serum levels in individuals with obesity and food addiction. The present study involved 30 adults with obesity (23 females and 7 males) and 10 healthy adults (5 females and 5 males). 18 obese adults were diagnosed with food addiction, whereas only 2 individuals with food addiction were in the control group. GH, GHR, IGF-1 and insulin values were analyzed with ELISA kits. It was revealed that the obese subjects had significantly lower serum IGF-1 levels compared to healthy individuals $(144.55 \pm 22.69 \mathrm{ng} / \mathrm{ml} \mathrm{vs} 338.70 \pm 61.90 \mathrm{ng} / \mathrm{ml}$, $P<0.001)$ ). No significant differences in the GH, GHR and insulin levels between obese and control groups were detected $(P>0.05)$. No significant differences between the group with food addiction and the group without food addiction in terms of gender, age, weight, BMI, GH, GHR, insulin and IGF-1 levels were observed. Our study demonstrates that normal IGF-1 levels may be protective for the development of obesity. The serum levels of GH, GHR, insulin, IGF-1 are not associated with food addiction and, therefore, can not be used as novel markers of food addiction.

Keywords: obesity, food addiction, growth hormone, growth hormone receptor, insulin-like growth factor 1.

$\mathrm{O}$ besity is a public health problem that increasingly becomes widespread and causes various complications. Food intake is vital for survival and regulated by homeostatic and hedonic mechanisms. Inadequate or excessive food intake that impairs energy balance is associated with high comorbidity and causes to serious health problems $[1,2]$. The increasing rate of obesity prevalence has revealed the significance of food addiction. Food addiction is a hedonic eating behavior characterized by overconsumption of palatable foods (ie, foods involve high amount of salt, sugar, and fat) [3]. The most common symptoms of food addiction are: 1 . loss of control in eating, 2. continous and increased amount of food intake despite the negative consequences. Therefore, food addiction can be associated with obesity and eating disorders [4]. Food intake that depends on the balance between hedonic and metabolic pathways is mainly controlled by the brain. Food addiction may disrupt the balance and then lead to the development of obesity [5].

Growth hormone $(\mathrm{GH})$ which is a single chain polypeptide composed of 191 amino acids is synthesized by somatotropic cells in the pituitary gland via hypothalamic-pituitary axis. GH that interacts with growth hormone receptor (GHR) is responsible for

(C) 2021 Avsar O. et al. This is an open-access article distributed under the terms of the Creative Commons Attribution License, which permits unrestricted use, distribution, and reproduction in any medium, provided the original author and source are credited. 
numerous biological functions such as regulation of growth, metabolism of lipids, carbohydrates, and proteins, regulation of glucose uptake and insulin secretion. Ghrelin hormone which is synthesized by the stomach is involved in the regulation of GH production and elevated ghrelin levels induce GH secretion. Insulin-like growth factor 1 (IGF-1) is implicated in the inhibiton of GH secretion [6, 7].

GH stimulates lipolysis and oxidation of lipids during long-term fasting. Obesity and type 2 diabetes which have been associated with insulin resistance are correlated with low amounts of GH release [8]. Disturbances in growth hormone signaling pathway have been associated with increased food intake and adiposity [9]. Despite particularly abdominal obesity has been shown to lead to decrease in GH release and IGF-1 levels, the relationship between GH and obesity is still unclear [10]. In the literature, no studies conducted with human samples in order to determine the relationship between food addiction and growth hormone.

In the present study, we aimed to investigate the relationship between obesity, food addiction, and growth hormone, growth hormone receptor, insulin, and insulin-like growth factor 1 values in Turkish population. In this regard, GH, GHR, IGF-1, and insulin levels were analyzed in serum of human subjects with obesity and/or food addiction.

\section{Materials and Methods}

Subjects. In the present study (non-drug/noninterventional clinical research), serum levels of human growth hormone (GH), growth hormone receptor (GHR), insulin-like growth factor-1 (IGF- 1), and insulin have been investigated in 2 groups. Group 1 $(n=30)$ was composed of overweight and obese individuals, whereas group $2(n=10)$ con- tained healthy individuals compatable with sex and age. Inclusion criteria of the study were: a. informed consent by volunteer, b. age between 18 and 48 years, c. BMI for healthy subjects: $18.5<$ and $<24.9$; BMI for obese: $\geq 30$; BMI for overweight: $25 \leq$ and $<30$. Exclusion criteria were: a. having metabolic disturbances such as diabetes and thyroid problems, b. using appetizing drugs such as steroids and antip- sychotics, c. smoking, d. being chronic alcoholic, e. being pregnant, f. being breastfeeding.

The current research was conducted based on the principles of Helsinki Declaration. The research permission was approved by Clinical Research Ethics Committe of University of Health Sciences
Istanbul Fatih Sultan Mehmet Education and Research Hospital (FSM EAH-KAEK 2019/21, date of approval: 28/03/2019). All volunteers were recruited at Endocrinology and Metabolic Diseases outpatient clinic of Fatih Sultan Mehmet Education and Re- search Hospital of University of Health Sciences for face-to-face interviews and blood collection. Measurement of weight and height values were carried out with standard medical equipment. The Yale Food Addiction Scale (YFAS) which was developed by Gearthardt et al. [11] in 2009 and the validation and reliability of Turkish version was secured by Bayrak- tar et al. [12] in 2012 was used for the diagnosis of food addiction in the current study.

Determination of circulating metabolic biomarkers. Serum GH, GHR, IGF-1, and insulin concentrations were determined by the enzyme-linked immunosorbent assay (Elabscience ELISA kits, USA) based on the manufacturer's instructions. All of the experiments were performed in duplicate to confirm the precision.

Statistical analysis. The statistical evaluation of the findings were done by SPSS 25.0 (SPSS Inc., Chicago, IL, USA). The ShapiroWilk and Kolmogorov-Smirnov tests were applied to determine whether the results with normal distribution or not. Quantitative parameters with normal distribution are shown as the means \pm standard deviations. Student's $t$-test or one-way ANOVA were applied in order to compare the numerical data. The comparison of categorical variables were performed by chi-square test $\left(\chi^{2}\right)$. The $P$-value $<0.05$ was considered statistically significant.

\section{Results and Discussion}

The present study involved 30 adults with obesity (23 females and 7 males) with the mean age of $29.43 \pm 8.42$ years. In the control group, the mean age of 10 adults ( 5 females and 5 males) was $28.60 \pm 4.55$ years. No significant differences between the control and obesity groups were observed in terms of gender and age $(P>0.05)$. The number of the subjects with food addiction was significantly higher in obese group compared to the control group $(P=0.029)$.

The weight of participants with obesity were significantly higher than the participants in the control group $(96.25 \pm 20.37 \mathrm{~kg}$ vs $68.70 \pm 13.91 \mathrm{~kg}$, $P<0.001)$. The subjects with obesity had statistically significant higher BMI values than healthy individuals (34.90 $\pm 6.67 \mathrm{~kg} / \mathrm{m} 2$ vs $22.84 \pm 1.66 \mathrm{~kg} /$ $\left.\mathrm{m}^{2}, P<0.001\right)$. 
The mean GH levels in the control and obese groups were $421.15 \pm 196.03 \mathrm{pg} / \mathrm{ml}$ and $529.38 \pm 309.32 \mathrm{pg} / \mathrm{ml}$, respectively. The mean GHR levels in the serum of the control and obese groups were $10.00 \pm 1.85 \mathrm{ng} / \mathrm{ml}$ and $9.60 \pm 2.01 \mathrm{ng} / \mathrm{ml}$, respec- tively. The mean serum insulin values in the control and obese groups were $6.17 \pm 1.28 \mathrm{mIU} / \mathrm{l}$ and $5.89 \pm 1.90 \mathrm{mIU} / \mathrm{l}$, respectively. There were no statistically significant differences between obese and control groups in terms of GH, GHR, and insulin $(P>0.05)$.

The healthy individuals had significantly higher serum IGF-1 levels compared to the subjects with obesity ( $338.70 \pm 61.90 \mathrm{ng} / \mathrm{ml}$ vs $144.55 \pm 22.69 \mathrm{ng} /$ $\mathrm{ml}, P<0.001)$. Demographic and biochemical data of healthy and obese individuals are seen in Table 1.
In the current study, obesity group was divided into 2 subgroups (food addiction (FA) and non food addiction (NFA)). The mean age of 18 obese adults diagnosed with food addiction (16 females and 2 males) were $28.5 \pm 7.54$ years. The mean age of 12 adults (7 females and 5 males) of the obese adults without food addiction diagnosis was $30.83 \pm 9.77$ years. No significant differences between FA and NFA groups in terms of gender, age, weight, BMI, GH, GHR, insulin, and IGF-1 were observed. Demographic and biochemical data of FA and NFA groups are shown in Table 2.

Obesity which is considered as both neurobiological and metabolic disease is one of the most significant health problems in the world [13]. The complex etiology of obesity and food addiction is

Ta b le 1. Demographic and clinical features and biochemical parameters of healthy and obese participants

\begin{tabular}{|l|c|c|c|c|c|}
\hline \multicolumn{1}{|c|}{ Variables } & \multicolumn{2}{|c|}{ Control group, $(n=10)$} & \multicolumn{2}{c|}{ Obese group, $(n=30)$} & $\begin{array}{c}\text { Statistical } \\
\text { analysis, } P\end{array}$ \\
\hline Male/Female, $n(\%)$ & \multicolumn{2}{|c|}{$5(50 \%) / 5(50 \%)$} & \multicolumn{2}{c|}{$7(23.4 \%) / 23(76.6 \%)$} & 0.117 \\
\hline FA/NFA, $n(\%)$ & \multicolumn{2}{|c|}{$2(20 \%) / 8(80 \%)$} & \multicolumn{2}{c|}{$18(60 \%) / 12(40 \%)$} & 0.029 \\
\hline & Mean & SD & Mean & SD & $P$ \\
\hline Age (years) & 28.60 & 4.55 & 29.43 & 8.42 & 0.695 \\
\hline Weight $(\mathrm{kg})$ & 68.70 & 13.91 & 96.25 & 20.37 & $<0.001$ \\
\hline BMI $\left(\mathrm{kg} / \mathrm{m}^{2}\right)$ & 22.84 & 1.66 & 34.90 & 6.67 & $<0.001$ \\
\hline GH $(\mathrm{pg} / \mathrm{ml})$ & 421.15 & 196.03 & 529.38 & 309.32 & 0.308 \\
\hline GHR (ng/ml) & 10.0 & 1.85 & 9.6 & 2.01 & 0.583 \\
\hline Insulin (mIU/l) & 6.17 & 1.28 & 5.89 & 1.90 & 0.669 \\
\hline IGF-1 (ng/ml) & 338.70 & 61.90 & 144.55 & 22.69 & $<0.001$ \\
\hline
\end{tabular}

FA: Food Addiction, NFA: Non Food Addiction, BMI: Body Mass Index, SD: Standard Deviation

Ta b le 2. Comparison of clinical and biochemical parameters among obesity subgroups

\begin{tabular}{|l|c|c|c|c|c|}
\hline \multicolumn{1}{|c|}{ Variables } & \multicolumn{2}{|c|}{ FA $(\mathrm{n}=18)$} & \multicolumn{2}{c|}{ NFA $(n=12)$} & Statistical analysis, $P$ \\
\hline Male/Female, $n(\%)$ & $2(11.1 \%) / 16(88.9 \%)$ & $5(41.7 \%) / 7(58.3 \%)$ & 0.055 \\
\hline & Mean & SD & Mean & SD & $P$ \\
\hline Age (years) & 28.5 & 7.54 & 30.83 & 9.77 & 0.467 \\
\hline Weight $(\mathrm{kg})$ & 96.94 & 23.85 & 95.208 & 14.58 & 0.824 \\
\hline BMI $\left(\mathrm{kg} / \mathrm{m}^{2}\right)$ & 35.89 & 7.69 & 33.41 & 4.70 & 0.329 \\
\hline GH $(\mathrm{pg} / \mathrm{ml})$ & 603.55 & 320.88 & 418.12 & 265.74 & 0.109 \\
\hline GHR $(\mathrm{ng} / \mathrm{ml})$ & 9.55 & 2.33 & 9.66 & 1.49 & 0.885 \\
\hline Insulin $(\mathrm{mIU} / \mathrm{l})$ & 5.77 & 2.08 & 6.06 & 1.68 & 0.686 \\
\hline IGF-1 $(\mathrm{ng} / \mathrm{ml})$ & 140.86 & 24.23 & 150.08 & 19.84 & 0.283 \\
\hline
\end{tabular}

FA: Food Addiction, NFA: Non Food Addiction, BMI: Body Mass Index, SD: Standard Deviation 
unclear. Therefore, the factors implicated in the development of obesity and food addiction are needed to be elucidated.

Growth hormone signaling is implicated in the modulation of growth, metabolism, and various physiological functions associated with cardiovascular, reproductive, hepatobiliary, gastrointestinal, and renal systems [14]. Deficiency of GH induces increased levels of body fat mass [15]. Deficiency of growth hormone receptor has been related to increased obesity risk and percentage of body fat [16]. In growth hormone-deficient subjects, it has been reported that increased adiposity can not be reduced by GH supplementation due to the decreased GHR expression [17].

IGF-1 and GH may affect differentiation and proliferation of adipocytes and there is interaction between pituitary, liver, and adipose tissue [18]. On the other hand, GH and IGF-1 values are controversial and the molecular mechanisms are needed to be elucidated in various human populations.

In a study conducted with morbid obese individuals, plasma IGF-1 values in obese individuals were lower compared to controls [19]. Consistently, our current study shows that IGF-1 levels are significantly lower in obesity group compared to healthy controls. In a study conducted with morbidly obese individuals, it has been reported that decreased serum IGF-1 levels are related with renal lesions [20].

Despite significant correlations between plasma $\mathrm{GH}$ and IGF-1 levels and eating disorders such as bulimia nervosa, anorexia nervosa [21], in the literature, no studies that investigated the relationship between food addiction and GH, GHR, insulin, and IGF-1 were found. Our results shows that serum GH, GHR, insulin, and IGF-1 concentrations are not associated with food addiction in Turkish patients.

In conclusion, the current study demonstrates: i) serum IGF-1 levels are significantly decreased in obese individuals and these decreased levels may be responsible for the development of obesity; ii) $\mathrm{GH}$, GHR, insulin, IGF-1 are not correlated with food addiction and therefore, can not be used as novel markers for food addiction.

Further various human populations studies are needed to fully investigate the correlation between GH, GHR, IGF-1 values and obesity and food addiction.
Conflict of interest. Authors have completed the Unified Conflicts of Interest form at http://ukrbiochemjournal.org/wp-content/uploads/2018/12/ coi_disclosure.pdf and declare no conflict of interest.

Acknowledgments. This study was supported by the Department of Scientific Research Projects of Hitit University (Project No: FEF19001.19.006).

\section{PIBHI ГОРМОНУ РОСТУ, РЕЦЕПТОРА ГОРМОНУ РОСТУ ТА ІНСУЛІНОПОДІБНОГО ФАКТОРА РОСТУ В СИРОВАТЦІ КРОВІ ПАЦІЕНТІВ ІЗ ОЖИРІННЯМ ТА ХАРЧОВОЮ ЗАЛЕЖНІСТЮ}

\section{O. Avsar ${ }^{1 凶}$, S. Sancak ${ }^{2}, I . K_{\text {Koroglu }}^{3}, E . A v c l^{4}$}

${ }^{1}$ Hitit University, Department of Molecular Biology and Genetics, Corum, Turkey;

${ }^{2}$ Fatih Sultan Mehmet Education and Research Hospital, Department of Endocrinology, Istanbul, Turkey;

${ }^{3}$ Arapgir Ali Özge State Hospital, Department of Internal Medicine, Malatya, Turkey;

${ }^{4}$ Health Sciences University, Department of Biochemistry, Ankara, Turkey;

凶e-mail: orcunavsar@hitit.edu.tr

Ожиріння $\epsilon$ проблемою громадського здоров'я, яка стає все більш поширеною i сричиняє різні ускладнення. Харчова залежність - це гедоністична харчова поведінка, що характеризується надмірним споживанням смачних продуктів (тобто продуктів, що містять велику кількість солі, цукру та жиру). Відомо, що порушення сигнального шляху гормону росту пов'язані з підвищеним споживанням їжі та ожирінням. Метою дослідження було визначення рівня гормону росту (GH), рецептора гормону росту (GHR), інсуліну та інсуліноподібного фактора росту 1 (IGF-1) у сироватці крові осіб із ожирінням та харчовою залежністю. Досліджено 30 дорослих із ожирінням (23 жінки та 7 чоловіків) та 10 здорових дорослих (5 жінок та 5 чоловіків). У 18 дорослих із ожирінням діагностовано харчову залежність, тоді як у контрольній групі було лише 2 особи 3 харчовою залежністю. Показники GH, GHR, IGF-1 та інсуліну проаналізовано за допомогою ELISA.Виявлено, що у людей з ожирінням 
рівень IGF-1 у сироватці крові був значно нижчим, ніж у здорових людей $(144,55 \pm 22,69$ нг/мл проти $338,70 \pm 61,90$ нг/мл, $P<0,001)$. Значних відмінностей у рівнях GH, GHR та інсуліну між групами 3 ожирінням та контрольною групою виявлено не було $(P>0,05)$. Значних відмінностей між групою 3 харчовою залежністю та групою без харчової залежності щодо статі, віку, ваги, BMI, рівнів GH, GHR, інсуліну та IGF-1 не виявлено. Показано, що нормальний рівень IGF-1 може бути захисним фактором розвитку ожиріння. Рівні GH, GHR, інсуліну, IGF-1 у сироватці крові не пов'язані $з$ харчовою залежністю i, отже, не можуть бути використані як нові маркери харчової поведінки.

К л ю чов і слова: ожиріння, харчова залежність, GH, GHR, IGF-1.

\section{References}

1. Aktar N, Qureshi NK, Ferdous HS. Obesity: A review of pathogenesis and management strategies in adult. Delta Med Coll J. 2017; 5(1): 35-48.

2. Novelle MG, Diéguez C. Food Addiction and Binge Eating: Lessons Learned from Animal Models. Nutrients. 2018;1 0(1): 71.

3. Schulte EM, Joyner MA, Potenz MN, Grilo CM, Gearhardt AN. Current considerations regarding food addiction. Curr Psychiatry Rep. 2015; 17(4): 563.

4. Ayaz A, Nergiz-Unal R, Dedebayraktar D, Akyol A, Pekcan AG, Besler HT, Buyuktuncer Z. How does food addiction influence dietary intake profile? PLoS One. 2018; 13(4): e0195541.

5. Mendoza J. Food intake and addictive-like eating behaviors: Time to think about the circadian clock(s). Neurosci Biobehav Rev. 2019; 106: 122132.

6. Vijayakumar A, Yakar S, Leroith D. The intricate role of growth hormone in metabolism. Front Endocrinol (Lausanne). 2011; 2: 32.

7. Nishad R, Mukhi D, Menon RK, Pasupulati AK. Growth hormone and metabolic homeostasis. Eur Med J Diabetes. 2018; 6(1): 78-87.

8. Salvatori R. Growth hormone deficiency in patients with obesity. Endocrine. 2015; 49(2): 304-306.

9. Recinella L, Leone S, Ferrante C, Chiavaroli A, Shohreh R , Di Nisio C, Vacca M, Orlando G, Salvatori R, Brunetti L. Effects of growth hormone-releasing hormone gene targeted ablation on ghrelin-induced feeding. Growth Horm IGF Res. 2017; 37: 40-46.

10. Rasmussen MH. Obesity, growth hormone and weight loss. Mol Cell Endocrinol. 2010; 316(2): 147-153.

11. Gearhardt AN, Corbin WR, Brownell KD. Preliminary validation of the Yale Food Addiction Scale. Appetite. 2009; 52(2): 430-436.

12. Bayraktar F, Erkman F, Kurtuluş E. Adaptation study of Yale food addiction Scale. Bull Clin Psychopharm. 2012; 22(Suppl 1): S38.

13. Avsar O, Kuskucu A, Sancak S, Genc E. Are dopaminergic genotypes risk factors for eating behavior and obesity in adults? Neurosci Lett. 2017; 654: 28-32.

14. Dehkhoda F, Lee CMM, Medina J, Brooks AJ. The Growth Hormone Receptor: Mechanism of Receptor Activation, Cell Signaling, and Physiological Aspects. Front Endocrinol (Lausanne). 2018; 9: 35.

15. Kreitschmann-Andermahr I, Suarez $P$, Jennings R, Evers N, Brabant G.GH/IGF-I regulation in obesity--mechanisms and practical consequences in children and adults. Horm Res Paediatr. 2010; 73(3): 153-160.

16. Guevara-Aguirre J, Teran E, Lescano D, Guevara A, Guevara C, Longo V, Gavilanes AWD. Growth hormone receptor deficiency in humans associates to obesity, increased body fat percentage, a healthy brain and a coordinated insulin sensitivity. Growth Horm IGF Res. 2020; 51: 58-64.

17. Erman A, Veilleux A, Tchernof A, Goodyer CG. Human growth hormone receptor (GHR) expression in obesity: I. GHR mRNA expression in omental and subcutaneous adipose tissues of obese women. Int J Obes (Lond). 2011; 35(12): 1511-1519.

18. Lewitt MS. The Role of the Growth Hormone/ Insulin-Like Growth Factor System in Visceral Adiposity. Biochem Insights. 2017; 10: 1178626417703995.

19. Juiz-Valiña $P$, Pena-Bello $L$, Cordido $M$, Outeiriño-Blanco $\mathrm{E}$, Pértega $\mathrm{S}$, VarelaRodriguez B, Garcia-Brao MJ, Mena E, SangiaoAlvarellos S, Cordido F. Altered GH-IGF-1 Axis in Severe Obese Subjects is Reversed after Bariatric Surgery-Induced Weight Loss and Related with Low-Grade Chronic Inflammation. J Clin Med. 2020; 9(8): 2614. 
20. Bancu I, Díaz MN, Serra A, Granada M, Lopez D, Romero R, Bonet J. Low Insulin-Like Growth Factor-1 Level in Obesity Nephropathy: A New Risk Factor? PLoS One. 2016; 11(5): e0154451.
21. Brambilla F, Santonastaso P, Caregaro L, Favaro A. Growth hormone and insulin-like growth factor 1 secretions in eating disorders: Correlations with psychopathological aspects of the disorders. Psychiatry Res. 2018; 263: 233-237. 